\title{
Xenophobia - evolved 'outgroup' hatred or product of a toxic social environment?
}

During May 2008, xenophobic attacks broke out against African migrants and refugees in Johannesburg, Durban and Cape Town, leading to at least 50 deaths and the displacement of several thousand people. These events attracted much media attention and were condemned by politicians, community leaders and academic institutions. Of course such crises provide good opportunities for politicians to make mileage, and their proclamations should be received with a healthy dose of scepticism. But, interestingly, some of the responses come fairly close to identifying real causal factors behind the xenophobic violence. For example, in a statement in mid-June, Jacob Zuma identified 'poverty' and 'poor service delivery' as the major factors behind the attacks.' He is quoted as saying, 'the conditions of the informal settlements themselves are actually responsible for people to behave in a particular way'. An academic in History at Wits University, writing in The Star newspaper, elaborated on this issue, identifying as causal the frustration and anger that has accumulated in poor urban squatter camps due to overcrowding, lack of housing, widespread unemployment and grinding conditions of poverty and degradation. ${ }^{2}$ And finally, Stephen Gelb, a visiting professor of Economics at Wits University, drew the focus onto the issue of economic inequality and its social consequences, stating that 'the problem of inequality is equally deep and intractable' and that while it was clear that the South African Government had addressed poverty, it was 'equally clear inequality has not been addressed at all'. ${ }^{3}$

The emergence of xenophobic violence in South Africa and the ensuing debate as to its causes provide us with an opportunity to consider the research evidence-base regarding its origins. Social, economic and political aspects of the environment are clearly favoured by commentators outside the health sector and academic medicine. But is this supported by health land particularly mental health)-related research relevant to the ugly phenomenon of xenophobia?

In a chapter (in the publication Psychopathology and Social Prejudice) dedicated to the psychological analysis of xenophobia, Harris offers three different but complementary explanations for the phenomenon. ${ }^{4}$ These include the 'scapegoating hypothesis', the 'isolation hypothesis' and the 'biocultural hypothesis'. These are not mutually exclusive but rather 'offer different levels of explanation for xenophobia within contemporary South Africa'. In elucidating the 'scapegoating hypothesis', Harris draws on the work of Tshitereke, who links xenophobia to the discontent and indignation that arises in a context where expectations of delivery are high and yet extreme inequalities and deprivation persist. ${ }^{5}$ Xenophobia is located within a context of social transition and change. 'People are more conscious of their deprivation than ever before ... This is the ideal situation for a phenomenon like xenophobia to take root and flourish. ${ }^{5}$ Tshitereke argues that political and social transition exposes 'the unequal distribution of resources and wealth in the country'. ${ }^{5}$ This author is not alone in making a link between social and economic inequality and xenophobia. ${ }^{6.8}$ Wilkinson, who has contributed greatly to the evidence supporting a relationship between inequality and various aspects of health, states without ambiguity that 'the most well-established environmental determinant of levels of violence is the scale of income differences between the rich and poor'. 6

South Africa is indeed a country of extreme inequalities, measured in both social and economic terms. According to the UNDP, South Africa ranks ninth highest out of 130 countries in terms of the GINI coefficient, which is a measure of income inequality. ${ }^{9}$ The gap between rich and poor is profound. In a context where expectations of change are high, persisting serious inequality gives rise to a variety of forms of violence including domestic violence, gender-related violence, criminal violence and xenophobic violence. There is, however, a school of thought, emanating particularly from the biological and evolutionary sciences, that argues in support of innate factors that make xenophobic violence different from other forms of violence.

The field of 'Evolutionary Psychology' (EP) is concerned with identifying and describing the adaptive evolutionary bases of human behavioural and psychological phenomena. Thus traits, which may or may not be viewed as abnormal and pathological in the modern context, are said to have 'survived' natural selection due to their 'adaptive' properties in the 'ancestral environment'. For example, phobic traits are viewed as having evolved over millions of years as adaptive psychological and behavioural phenomena that protected human ancestors from threatening organisms and dangerous circumstances. It turns out that one of the more favoured topics of EP is that of violence, 10,11 and in particular forms of violence directed by groups against other groups. ${ }^{12,13}$ Drawing on such notions as 'kinship' and 'inclusive fitness', authors in this field argue that innate tendencies to identify closely with one's own group (the 'ingroup') and to be hostile towards members of other groups (the 'outgroup') proved adaptive during our evolutionary history in terms of ensuring personal and kin survival. For example, Goetze and James write: 'Behaviors that served as responses to threats from other 
humans may have been necessary for immediate survival and became adaptive as threat circumstances were repeated over the generations. ${ }^{13}$ These authors go on to state: 'One can imagine that an array of menacing stimuli provokes defensive reactions ... A plausible speculation is that murderous threats and actions directed at members of an ethnic group due to their ethnic identity are included among the array of menacing stimuli.."13 Such speculations rely heavily on antisocial behaviours observed in nonhuman primates - for example collective violence of chimpanzees against 'outgroup' members ${ }^{14}$ - with authors arguing that these observations in close human relatives are proof of an evolved innate basis for 'outgroup' violence, including xenophobia.

While seemingly attractive as biological explanations for psychological and behavioural phenomena, hypotheses emanating from EP should be viewed with caution. The discipline has been criticised (quite rightly) for its speculative nature and for its tendency to construct elaborate and sometimes quite fanciful 'Just So Stories' that are impossible to test empirically and too often neglect a firm basis in neuroscience. ${ }^{15}$ Furthermore, the discipline of EP is the natural descendant of another discipline, Sociobiology, which had a mixed reception in academic circles owing to its apparent origins in Social Darwinism and Eugenics. Champions of EP deny vigorously any similarities or relationship between their discipline and the notorious earlier movements that espoused racial purity and gave implicit support to racist political agendas. However, it is not difficult to detect reactionary strains within contemporary EP literature. For example, a scan of the EP literature - both published and web-based - reveals a range of clearly reactionary ${ }^{11}$ and implicitly racist writings ${ }^{16}$ providing evolutionary explanations (justifications?) for rape, genocide, xenophobia and racial purification. It is only too easy, in the name of intellectual debate, to take the step from arguing for an evolved genetic basis for unsavoury human attitudes and behaviours to providing a 'scientific' basis for nefarious political positions.

In conclusion, it would be naive and misleading to deny our evolutionary history and the part played by our genetic heritage in modern human psychology and behaviour. However, it is perhaps more misleading to ignore the impressive emerging literature ${ }^{17-19}$ focused on gene-environment interactions, epigenetic processes and the significant variability that exists in the phenotypic expression of inherited genetic material in our species. This evidence unambiguously supports a major role for environment in determining what innate properties are expressed. Xenophobia is a noxious social phenomenon that does not manifest in healthy socioeconomic environments. Where poverty, deprivation and especially economic and social inequality characterise a society or community, xenophobia is likely to emerge. In this respect, recent commentators on the causes of xenophobia in South Africa seem to have got it right. The challenge we face in our efforts to eradicate this disturbing phenomenon is to redress the serious inequities of our society so that foreigners landing on our shores discover a peaceful haven rather than a living hell.

\section{Jonathan Kenneth Burns}

\section{Department of Psychiatry}

Nelson R Mandela School of Medicine

University of KwaZulu-Natal

\section{Durban}

1. SAPA. Zuma on xenophobia. SAPA Online, 22 June 2008. hitp://news. iafrica.com/ sa/880958. htm (accessed 20 August 2008).

2. Nieftagodien N. Incoherent responses to Crisis. Wits News Room Online, 18 June 2008. http://web.wits.ac.za/NewsRoom/Newsltems/Noor+Nieftagodien+ xenophobia+opinion. htm (accessed 20 August 2008)

3. Magubane K. Academics unpack xenophobia. MediaClub SA Online. http://www. mediaclubsouthafrica.com/index. php? option=com_content\&view=article\&id $=46$ 2\%3Aacademics-unpack-xenophobia\&catid=44\%3Adevelopmentnews\&ltemid $=52$ (accessed 20 August 2008).

4. Harris B. Xenophobia: a new pathology for a New South Africa? In: Hook D, Eagle G, eds. Psychopathology and Social Prejudice. Cape Town: University of Cape Town Press, 2002: 169-184.

5. Tshitereke C. Xenophobia and relative deprivation. Crossings 1999; 3(2): 4-5.

6. Wilkinson R. Why is violence more common where inequality is greater? Ann NY Acad Sci 2004; 1036: 1-12

7. Wood A. Empirical studies of the correlation between social and economic inequalities and violence. International Conference of the World Organisation Against Torture, 2005. http://www.omct.org (accessed 20 August 2008).

8. Scheper-Hughes N. Dangerous and endangered youth: social structures and determinants of violence. Ann N Y Acad Sci 2004; 1036: 13-46.

9. UNDP. GINI Index. Human Development Reports, 2007/2008. http://hdrstats.undp. org/indicators/ 147.html (accessed 20 August 2008)

10. Daly M, Wilson M. Homicide. New York: Aldine, 1988

11. Thornhill R, Palmer CT. A Natural History of Rape: Biological Bases of Sexual Coercion. Cambridge, Mass: MIT Press, 1988

12. Ridley M. The Origins of Virtue: Human Instincts and the Evolution of Cooperation. New York: Penguin, 1996

13. Goetze DB, James P. Evolutionary Psychology and the explanation of ethnic phenomena. Evolutionary Psychology 2004; 2: 142-159

14. Wrangham RW, Wilson ML. Collective violence: comparisons between youths and chimpanzees. Ann N Y Acad Sci 2004; 1036: 233-256.

15. Burns JK. The Descent of Madness: Evolutionary Origins of Psychosis and the Social Brain. Hove, Sussex: Routledge Press, 2007; 46-49

16. Nuenke M. Hate, fear and disgust: evolutionary emotions for tribal survival. NeoEugenics Website www.neoeugenics.com (accessed 20 August 2008. )

17. Van Os J, Sham P. Gene-environment correlation and interaction in schizophrenia. In: Murray RM, Jones PB, Susser E, Van Os J, Cannon M, eds. The Epidemiology of Schizophrenia. Cambridge: Cambridge University Press, 2003.

18. Gregory AM, Lau JY, Eley TC. Finding gene-environment interactions for generalised anxiety disorder. Eur Arch Psychiatry Clin Neurosci 2008; 258(2): 69-75.

19. Bennett AJ. Gene environment interplay: nonhuman primate models in the study of resilience and vulnerability. Dev Psychobiol 2008; 50(1): 48-59. 